\title{
Associations Between Neighborhood Violence During Pregnancy and Birth Outcomes: Evidence From São Paulo's Western Region Birth Cohort
}

Angelica Carreira dos Santos ( $\sim$ angelica.carreira@usp.br)

Universidade de São Paulo Faculdade de Medicina https://orcid.org/0000-0002-3937-0258

Alexandra Brentani

Universidade de Sao Paulo

Günther Fink

Schweizerisches Tropen- und Public Health-Institut

Research article

Keywords: Violence, pregnancy, child health, birth weight, social determinants of health.

Posted Date: July 27th, 2020

DOl: https://doi.org/10.21203/rs.3.rs-40469/v1

License: (c) (i) This work is licensed under a Creative Commons Attribution 4.0 International License.

Read Full License 


\section{Abstract}

Background: Low birth weight and prematurity remain leading causes of infant mortality and morbidity globally. Although an extensive literature has highlighted the importance of socioenvironmental characteristics for birth outcomes, the role of indirect violence on health remains fairly understudied.

Methods: Using geocoded birth records from the ongoing Western Region Birth Cohort (Região Oeste Coorte - ROC-Cohort) of infants born between 2012-2014 and geocoded crime reports, we assessed the associations between exposure to violent crimes during pregnancy within a 1-km radius of mother's residence and low birth weight, preterm delivery, and being born small-for-gestational-age. Violent crime exposure was categorized into quintiles. Multivariate logistic regressions were used to examine the associations between violence exposure and birth outcomes. Models were adjusted for sex, maternal age and education, socioeconomic status, and risk factors such as hypertension, diabetes, smoking, and drinking during pregnancy.

Results: Among the 5,268 infants included, the average crime exposure during the first two trimesters of pregnancy ranged from 0.44 violent crimes in the least exposed quintile to 12.74 crimes in the most exposed. Compared to children with the lowest violence exposure, children in the highest exposure quintile were at higher odds of being born small-for-gestational-age (1.41[1.06-1.89]), preterm (1.35[1.01$1.80])$, and low birth weight (1.42[1.03-1.98]). While socioeconomic status and maternal education were positively associated with lower violence exposure, no associations were found between these characteristics and the birth outcomes.

Conclusions: Higher exposure to external violent crimes in the close vicinity are associated with substantial increases in the odds of adverse birth outcomes. Policies to improve neighborhood safety can contribute not only to the short-term well-being of populations but may also have large social, economic, and health benefits in the long run.

\section{Background}

Low birth weight accounts for more than $80 \%$ of all neonatal mortality globally [1]. In 2015, more than 1 million children under 5 died because of preterm birth complications globally [2]. Neonates born with low birth weight - about two-thirds of which are preterm [1] - face higher morbidity risks, increased risk of stunting, increased risk of long-term development impairment, as well as increased vulnerability to chronic disease [1-7].

Violence is a growing public health concern with immediate and long-term influences on population health [8-10]. Contrary to some positive trends observed in high-income countries (HIC) in recent years [10], homicide rates have been increased in Latin America over the past years [11]. An estimated homicide rate of 28.5 implies that crime rates in Latin America are 8 times higher than those seen in HICs on average, and 14 times those seen in low-middle-income countries (LMICs) in the Western Pacific Region [11]. 
Exposure to violence has been consistently associated with mental health problems and high-risk behaviors such as alcohol, smoking, and drug abuse, which threaten the wellbeing of both adult and child populations $[9,12,13]$. Fear of crime can also trigger anxiety and feelings of isolation, victimization, powerlessness, and normlessness [14], particularly among women [15]. Chronic exposure to such environmental stress can trigger neural or neuroendocrine responses, change the functioning of the hypothalamic-pituitary-adrenal axis and lead to increased allostatic load [16].

A growing body of literature has also tried to link the area-level effects of external violence to adverse birth outcomes [17-26]. The large majority of studies are based on neighborhood comparisons in the United States, and likely allow only limited insight into the impact of violence in low-income settings due to the large structural differences in neighborhoods as well as public support systems. The few studies that have been conducted in low-income and high crime exposure areas have mostly focused on sociopolitical violence, and generally found sizeable increases in adverse birth outcomes in response to major violence outbreaks $[17,20,27,28]$. This is consistent with other studies focusing on more extreme forms of violence, such as terrorist attacks and civil/war conflicts, finding large increases in the risk of pregnancy complications outcomes after such major events [17, 29].

We aim to explore the relationship between exposure to violent crime in close vicinity and three of the most common adverse birth outcomes: preterm birth, small-for-gestational-age, and low birth weight in one of the largest metropolitan areas of the world [30]. Using a novel data set, we aim to fulfill the gap in the literature that investigates the underlying consequences of violent crimes in the health of pregnant women and their offspring in a low-income population. Our initial hypothesis is that violent crime close to home is associated with these adverse birth outcomes, independent of maternal and socioenvironmental characteristics.

\section{Methods}

\section{Study design}

This study was designed as a retrospective cross-sectional study linking data collected as part of a prospective cohort study to geocoded administrative data on violent crime.

\section{Study Setting}

This study was conducted in São Paulo, Brazil. Like other LMICs, Brazil has experienced a rapid and mostly unmanaged urbanization process in the past decades, accompanied by large increases in social and economic inequality [31,32]. The rates of homicides in Brazil have been rising steadily over the past years, reaching a record level of 31.6 homicides per 100,000 inhabitants in 2017 [33]. With 10.3 homicides per 100,000 inhabitants, São Paulo municipality had one of the lowest homicide rates in Brazil in 2017 overall, but very high rates in areas of low socioeconomic development [33]. In the Western Region of São Paulo, where this study was conducted, homicide rates ranged in its neighborhoods between 5 and 20 homicides per 100,000 inhabitants [34]. 


\section{Study Population}

The Western Region Birth Cohort (Região Oeste Coorte - ROC-Cohort) enrolled all locally resident infants born at the University Hospital of the School of Medicine of the University of São Paulo between April 1, 2012, and March 31, 2014. A total of 6,207 mother-child pairs were enrolled in the cohort. The cohort is still active, with children currently under the 72 months follow-up.

\section{Data}

Hospital electronic birth records were available for all children in the cohort. The electronic medical registry includes birth characteristics such as type of delivery, gestational length, weight at birth, and others. During the postpartum hospital stay, trained interviewers administrated structured questionnaires to collect information on socio-demographic characteristics and health during pregnancy to a subset of mothers. The questionnaire can be found in the Supplementary file 1.

\section{Outcomes}

The analysis focused on three adverse birth outcomes: low birth weight (LBW), preterm delivery (PT), and small-for-gestational-age (SGA). Birth weight and length were measured by the Hospital's neonatology team immediately after birth using standard hospital equipment. Gestational length in weeks was estimated using the New Ballard Score [35]. LBW was defined as birth weight $<2,500$ grams, and SGA was defined as weight-for-gestational age $<10^{\text {th }}$ percentile based on the Intergrowth-21th growth reference tables [36].

\section{Exposure - violence in the neighborhood}

Data on violence is routinely collected and made publicly available by the Secretariat of Public Safety of the State of São Paulo (www.ssp.sp.gov.br). The system collects detailed information about willful murder, femicide, robbery followed by death, bodily injury followed by death, death resulting from police intervention, suspicious death, fatal vehicle accidents, and mobile theft. Each reported incident record contains the date, time, and address of the crime. Following most of the external violence literature, we focused on violent crime in our analysis, which includes willful murder, robbery followed by death, bodily injury followed by death and death resulting from police intervention, but excludes other crimes such as robberies without injuries.

We extracted data on violent crimes between 2011 and 2014 to cover the pregnancy period of all ROCCohort children. The address of each reported crime was geocoded with latitude and longitude coordinates using the ggmap package [37], and a point-layer for each time point (month-year) was generated using $\mathrm{R}$ map tools [38]. The maternal residential address was collected at birth and geocoded as an additional point-layer. Each residential address was treated as a centroid point. We then computed the number of crimes within a 1-kilometer spatial buffer by day, month and year. Exposure to violence during pregnancy was estimated as the sum of violent crimes in the first two trimesters of pregnancy. 
Violence in the third trimester was not considered because total exposure to violence after week 24 of gestation directly depends on gestational length (the outcome variable). Violence exposure during the first two trimesters was then divided into five equally sized quintiles for analysis.

\section{Statistical analyses}

We first compute the average number of crimes for each of the exposure quintiles. Next, we tested crude associations of exposure to violence quintiles with each outcome (LBW, SGA, and PT birth). In the fully adjusted multivariable models, we included all covariates highlighted in the extant literature as risk factors for adverse birth outcomes, including maternal age (<20, >=35), educational level, alcohol consumption, diabetes and hypertension during pregnancy, and socioeconomic (SES) index. The construction of a socioeconomic (SES) index was based on the approach proposed by Vyas and Kumaranayake [39], which relies on the use of principal component analysis (PCA) to the selected variables. The SES index variable describes the SES status based on questions about ownership of durables, income, and house characteristics. The resulting SES index was then divided into quintiles - low, medium-low, medium, medium-high, and high SES status. Age was measured as a continuous variable but categorized in the adjusted model to take into account the risks of pregnancy in different ages range (adolescence, adulthood, and after 35 years old).

Given that the postpartum questionnaire was only available for a subsample of children, we initially screened the dataset for missing data and patterns of non-responsiveness in the postpartum questionnaire using t-test and chi-square to test if the assumptions of missing at random (MAR) were met. We implemented multiple imputations by chained equations (MICE) with a fully conditional specification of prediction equations using variables that potentially predicted non-response or the outcome. The MICE method accounts for statistical uncertainty in the imputations, resulting in more plausible imputes, and hence more reliable inferences in complex settings. Further details on these imputations are provided in the Table $\mathbf{S 1}$ (Supplementary file 2). All analyses were performed using Stata version 14 [40] and $\mathrm{R}$ version 3.6.1 [38].

\section{Results}

Among the 6,207 children in the ROC-Cohort, 44 were stillbirths and excluded from the analysis. Stillbirth was not associated with violence exposure during pregnancy in our sample $(0.99 ; 95 \% \mathrm{Cl}$ : $0.92-1.06)$. Additionally, 895 mother-child dyads were excluded due to an invalid address. Overall, 5,268 children and their mothers met the inclusion criteria for this study. Mothers who did not respond to the postpartum questionnaire did not differ from those who completed the survey regarding the type of birth, gestational length category, birth weight and length, and child sex.

398 (7.8\%) births were classified as SGA, $369(7.0 \%)$ as PT, and $355(6.7 \%)$ as LBW. Table 1 shows the frequency of each type of crime during pregnancy by exposure quintile. During the first two trimesters, the mean number of crimes exposition within a 1-kilometer from home was 4.2 (SD \pm 4.8$)$. The large majority of violent crimes were classified as murders; death resulting from policy intervention was the second 
most common type of violent crime. Women with the lowest exposure in the sample (quintile 1) were exposed to $0.45(S D \pm 0.5)$ violent crimes on average. Only $19 \%$ of women did not experience any exposition to violent crimes in their vicinity during the first two trimesters. In the fifth quintile, women were exposed on average to 12.7 ( $S D \pm 4.5$ ) violent crimes, with some women experiencing more than 30 violent crimes during the first two trimesters.

Table 1

Frequency of violent crime type in pregnancy per exposure quintile.

\begin{tabular}{|llllll|}
\hline & $\begin{array}{l}\text { 1st } \\
\text { quintile }\end{array}$ & $\begin{array}{l}\text { 2nd } \\
\text { quintile }\end{array}$ & $\begin{array}{l}\text { 3rd } \\
\text { quintile }\end{array}$ & $\begin{array}{l}\text { 4th } \\
\text { quintile }\end{array}$ & $\begin{array}{l}\text { 5th } \\
\text { quintile }\end{array}$ \\
\hline Murder & $0.39 \pm$ & $1.71 \pm$ & $2.64 \pm$ & $4.34 \pm$ & $9.08 \pm$ \\
& 0.49 & 0.67 & 0.71 & 1.38 & 2.85 \\
\hline Assault followed by death & $0.26 \pm$ & $0.26 \pm$ & $0.29 \pm$ & $0.48 \pm$ & $0.65 \pm$ \\
& 0.65 & 0.65 & 0.65 & 0.90 & 1.50 \\
\hline Bodily injury followed by death & $0.01 \pm$ & $0.02 \pm$ & $0.01 \pm$ & 0 & 0 \\
& 0.08 & 0.12 & 0.10 & & \\
\hline $\begin{array}{l}\text { Death resulting from police } \\
\text { intervention }\end{array}$ & 0 & $0.01 \pm$ & $0.06 \pm$ & $0.22 \pm$ & $3.02 \pm$ \\
\hline
\end{tabular}

Figure 1 shows the geographic distribution of the outcomes and violent crimes in the studied area. Areas colored in red represent the highest crime exposure; blue areas are safest. Panel A of Figure one shows the overall spatial distribution of children in the study area. Panels B, C, and D illustrate the spatial distribution of the three adverse birth outcomes

Areas on the first, third, and fifth quintile of violent crimes had $6.7 \%, 7.9 \%$, and $9.5 \%$ of SGA children, $6.5 \%$, $6.4 \%$, and $6.3 \%$ of PT, and $5.4 \%, 7 \%$ and $7.5 \%$ of born LBW children, respectively. Table 2 shows the distribution of SGA, PT, and LBW birth outcomes by exposure quintile. In bivariate analysis, LBW was strongly associated with crime exposure $(1.09 ; 95 \% \mathrm{Cl}: 1.02-1.17, \mathrm{p}=0.014)$, while PT and SGA displayed positive but not statistically significant associations with violent crimes. Upper middle $(0.91 ; 95 \% \mathrm{Cl}$ : $0.85-0.98, p=0.013)$ and high $(0.83 ; 95 \% \mathrm{Cl}: 0.77-0.89, \mathrm{p}<0.001)$ SES status was negatively associated with violent crimes. Physical abuse was also negatively associated with violence $(0.79 ; 95 \% \mathrm{Cl}: 0.66-0.95$, $p=0.013)$. 
Table 2

Birth outcomes and child and family characteristics by external violence exposure quintile.

\begin{tabular}{|c|c|c|c|c|c|c|c|c|}
\hline \multirow{3}{*}{$\begin{array}{l}\text { Violent crimes quintile } \\
\text { Number of occurrences }\end{array}$} & \multirow{2}{*}{\multicolumn{2}{|c|}{$\begin{array}{l}\text { 1st quintile } \\
\text { Low: } 0-1\end{array}$}} & \multirow{2}{*}{\multicolumn{2}{|c|}{$\begin{array}{l}\text { 3rd quintile } \\
\text { Medium: } 3\end{array}$}} & \multirow{2}{*}{\multicolumn{2}{|c|}{$\begin{array}{l}\text { 5th quintile } \\
\text { High: 8-37 }\end{array}$}} & \multirow{3}{*}{$\begin{array}{l}\text { OR } \\
(95 \% \mathrm{Cl})\end{array}$} & \multirow[t]{3}{*}{ p } \\
\hline & & & & & & & & \\
\hline & $\mathbf{n}$ & $\%$ & $\mathbf{N}$ & $\%$ & $\mathbf{n}$ & $\%$ & & \\
\hline \multicolumn{9}{|l|}{$\operatorname{SGA}(N=5,080)$} \\
\hline Yes & 116 & 6.7 & 36 & 7.9 & 87 & 9.5 & $\begin{array}{l}1.06 \\
(1.00- \\
1.14)\end{array}$ & 0.062 \\
\hline \multicolumn{9}{|l|}{ PT $(N=5,268)$} \\
\hline Yes & 116 & 6.5 & 30 & 6.4 & 61 & 6.3 & $\begin{array}{l}1.02 \\
(0.95- \\
1.09)\end{array}$ & 0.594 \\
\hline \multicolumn{9}{|l|}{ LBW $(N=5,268)$} \\
\hline Yes & 96 & 5.4 & 33 & 7.0 & 72 & 7.5 & $\begin{array}{l}1.09 \\
(1.02- \\
1.17)\end{array}$ & 0.014 \\
\hline \multicolumn{9}{|l|}{ Fetal $\operatorname{sex}(N=5,268)$} \\
\hline Female & 898 & 50.2 & 246 & 52.1 & 469 & 48.7 & $\begin{array}{l}1.00 \\
(0.96- \\
1.03)\end{array}$ & 0.937 \\
\hline \multicolumn{9}{|l|}{ Maternal age $(\mathrm{N}=5,268)$} \\
\hline$<20$ years & 381 & 21.3 & 93 & 19.7 & 239 & 24.8 & $\begin{array}{l}1.03 \\
(0.99- \\
1.07)\end{array}$ & 0.157 \\
\hline $20-35$ years & 1191 & 66.6 & 327 & 69.5 & 626 & 64.9 & & Ref. \\
\hline$>35$ years & 216 & 12.1 & 52 & 11.0 & 99 & 10.3 & $\begin{array}{l}0.96 \\
(0.90- \\
1.01)\end{array}$ & 0.125 \\
\hline \multicolumn{9}{|l|}{ Skin color $(N=5,267)$} \\
\hline White & 1080 & 60.4 & 286 & 60.7 & 593 & 61.5 & & Ref. \\
\hline Non-white & 707 & 39.6 & 186 & 39.4 & 371 & 38.5 & $\begin{array}{l}1.00 \\
(0.96- \\
1.03)\end{array}$ & 0.888 \\
\hline SES status $(\mathrm{N}=2,709)$ & & & & & & & & \\
\hline
\end{tabular}

Quintiles categorized violent crimes within a 1-kilometer from participants' home address; OR: odds ratio; 95\% Cl: 95\% confidence interval; SGA: small for gestational age; PT preterm; LBW: low birth weight; SES: socioeconomic status• 


\begin{tabular}{|c|c|c|c|c|c|c|c|c|}
\hline \multirow{3}{*}{$\begin{array}{l}\text { Violent crimes quintile } \\
\text { Number of occurrences } \\
\text { Low }\end{array}$} & \multirow{2}{*}{\multicolumn{2}{|c|}{$\begin{array}{l}\text { 1st quintile } \\
\text { Low: 0-1 }\end{array}$}} & \multirow{2}{*}{\multicolumn{2}{|c|}{$\begin{array}{l}\text { 3rd quintile } \\
\text { Medium: } 3\end{array}$}} & \multirow{2}{*}{\multicolumn{2}{|c|}{$\begin{array}{l}\text { 5th quintile } \\
\text { High: 8-37 }\end{array}$}} & \multirow{3}{*}{$\begin{array}{l}\text { OR } \\
\begin{array}{l}(95 \% \mathrm{Cl}) \\
\end{array} \\
1.08 \\
(1.00- \\
1.16)\end{array}$} & \multirow{3}{*}{$\begin{array}{l}\mathbf{p} \\
0.045\end{array}$} \\
\hline & & & & & & & & \\
\hline & 144 & 16.0 & 45 & 18.0 & 128 & 24.6 & & \\
\hline Lower-middle & 225 & 25.1 & 66 & 27.9 & 156 & 30.0 & & Ref. \\
\hline Middle & 126 & 14.0 & 40 & 16.9 & 79 & 15.2 & $\begin{array}{l}0.98 \\
(0.91- \\
1.06)\end{array}$ & 0.605 \\
\hline Upper-middle & 213 & 23.7 & 91 & 20.3 & 104 & 20.0 & $\begin{array}{l}0.91 \\
(0.85- \\
0.98)\end{array}$ & 0.013 \\
\hline High & 190 & 21.2 & 79 & 16.0 & 53 & 10.2 & $\begin{array}{l}0.83 \\
(0.80- \\
0.89)\end{array}$ & $<.001$ \\
\hline \multicolumn{9}{|l|}{ Education $(\mathrm{N}=3,256)$} \\
\hline Incomplete primary & 154 & 13.2 & 44 & 15.8 & 109 & 18.9 & $\begin{array}{l}1.07 \\
(1.01- \\
1.14)\end{array}$ & 0.026 \\
\hline Complete secondary & 934 & 80.0 & 216 & 77.7 & 452 & 78.5 & & Ref. \\
\hline Tertiary & 79 & 6.8 & 18 & 6.5 & 15 & 2.6 & $\begin{array}{l}0.83 \\
(0.13- \\
0.19)\end{array}$ & $<0.001$ \\
\hline \multicolumn{9}{|l|}{ Diabetes $(N=3,246)$} \\
\hline Yes & 36 & 3.1 & 6 & 2.2 & 16 & 2.8 & $\begin{array}{l}0.95 \\
(0.83- \\
1.09)\end{array}$ & 0.500 \\
\hline \multicolumn{9}{|l|}{ Hypertension $(\mathrm{N}=3,249)$} \\
\hline Yes & 130 & 11.2 & 21 & 7.6 & 51 & 8.9 & $\begin{array}{l}0.95 \\
(0.88- \\
1.03)\end{array}$ & 0.189 \\
\hline \multicolumn{9}{|l|}{$\begin{array}{l}\text { Smoke in pregnancy }(\mathrm{N} \\
=3,240)\end{array}$} \\
\hline Yes & 161 & 14.0 & 37 & 13.3 & 83 & 14.4 & $\begin{array}{l}0.99 \\
(0.93- \\
1.06)\end{array}$ & 0.802 \\
\hline
\end{tabular}




\begin{tabular}{|c|c|c|c|c|c|c|c|c|}
\hline \multirow{2}{*}{$\begin{array}{l}\text { Violent crimes quintile } \\
\text { Number of occurrences }\end{array}$} & \multirow{2}{*}{\multicolumn{2}{|c|}{$\begin{array}{l}\text { 1st quintile } \\
\text { Low: 0-1 }\end{array}$}} & \multirow{2}{*}{\multicolumn{2}{|c|}{$\begin{array}{l}\text { 3rd quintile } \\
\text { Medium: } 3\end{array}$}} & \multirow{2}{*}{\multicolumn{2}{|c|}{$\begin{array}{l}\text { 5th quintile } \\
\text { High: 8-37 }\end{array}$}} & \multirow{2}{*}{$\begin{array}{l}\text { OR } \\
(95 \% \mathrm{Cl})\end{array}$} & \multirow[t]{2}{*}{ p } \\
\hline & & & & & & & & \\
\hline \multicolumn{9}{|l|}{$\begin{array}{l}\text { Drink in pregnancy }(\mathrm{N}= \\
3,245)\end{array}$} \\
\hline Yes & 161 & 13.9 & 40 & 14.4 & 66 & 11.4 & $\begin{array}{l}0.94 \\
(0.88- \\
1.01)\end{array}$ & 0.079 \\
\hline \multicolumn{9}{|l|}{ Depression $(N=3,251)$} \\
\hline Yes & 34 & 2.9 & 3 & 1.1 & 9 & 1.6 & $\begin{array}{l}0.93 \\
(0.81- \\
1.07)\end{array}$ & 0.329 \\
\hline \multicolumn{9}{|l|}{$\begin{array}{l}\text { Physical abuse }(\mathrm{N}= \\
3,236)\end{array}$} \\
\hline Yes & 27 & 2.3 & 4 & 1.5 & 7 & 1.2 & $\begin{array}{l}0.79 \\
(0.66- \\
0.95)\end{array}$ & 0.013 \\
\hline
\end{tabular}

Figure 2 shows the bivariate relationship between exposure to violent crime and the proportion of infants born SGA (panel a), preterm (panel b) and LBW (panel c). Table 3 shows the unadjusted and adjusted associations between violent crime exposure during pregnancy and adverse birth outcomes. Relative to children from the lowest violence quintile, living in the highest violence quintile was associated with a $46 \%$ increase in the odds of SGA in the unadjusted model (1.46; 95\% Cl: 1.10-1.93). After adjustment for covariates, risk factors and SES status, the estimated odds ratio (OR) slightly decreased $(1.41 ; 95 \% \mathrm{Cl}$ : 1.06-1.89). In the adjusted model, PT birth odds increased nonlinearly (Fig. 2) with violence exposure, varying the estimated ORs from $1.16(95 \% \mathrm{Cl}: 0.84-1.59)$ on quintile $2,1.35$ (95\% $\mathrm{Cl}: 1.01-1.80)$ on quintile 4 , and 1.01 (95\% Cl: $0.72-1.40)$ on quintile 5 . The estimated risk of LBW increased almost linearly with exposure quintiles, with an estimated OR of 1.43 (95\% Cl: $1.03-1.98)$ for the top quintile. In terms of the included covariates, smoking during pregnancy was the most consistent risk factor for all birth outcomes analyzed in this study, with estimated ORs of 1.83 for SGA (95\% Cl: 1.32-2.55), 2.04 for PT birth (95\% Cl: 1.47-2.82), and 2.89 for LBW (95\% Cl: 2.07-4.03). Physical abuse during pregnancy more than doubled the odds for LBW $(2.12 ; 95 \% \mathrm{Cl}: 1.03-4.36, \mathrm{p}=0.042)$. SES and maternal education were not associated with the outcomes in our analysis. 
Table 3

Unadjusted and adjusted analyses between violent crimes exposure during pregnancy by quintiles, and birth outcomes.

\begin{tabular}{|c|c|c|c|c|c|c|}
\hline & \multicolumn{3}{|c|}{ Unadjusted } & \multicolumn{3}{|c|}{ Adjusted* } \\
\hline & OR & $95 \% \mathrm{IC}$ & $\mathrm{P}$ & OR & $95 \% \mathrm{IC}$ & $\mathrm{p}$ \\
\hline \multicolumn{7}{|c|}{ Small-for-gestational-age } \\
\hline \multicolumn{7}{|l|}{ Violent crimes } \\
\hline 1st quintile & Ref. & & & & & \\
\hline 2nd quintile & 1.36 & $1.02-1.83$ & 0.039 & 1.34 & $1.00-1.80$ & 0.054 \\
\hline 3rd quintile & 1.20 & $0.82-1.75$ & 0.349 & 1.19 & $0.81-1.75$ & 0.373 \\
\hline 4th quintile & 1.12 & $0.84-1.50$ & 0.418 & 1.11 & $0.84-1.50$ & 0.449 \\
\hline 5th quintile & 1.46 & $1.10-1.93$ & 0.009 & 1.41 & $1.06-1.89$ & 0.019 \\
\hline Physical abuse & & & & 1.07 & $0.43-2.65$ & 0.896 \\
\hline Depression & & & & 0.42 & $0.13-1.36$ & 0.147 \\
\hline Diabetes & & & & 0.70 & $0.27-1.82$ & 0.468 \\
\hline Hypertension & & & & 1.27 & $0.82-1.95$ & 0.286 \\
\hline Smoke & & & & 1.83 & $1.32-2.55$ & $<0.001$ \\
\hline Drink & & & & 1.43 & $0.99-2.05$ & 0.055 \\
\hline \multicolumn{7}{|l|}{ Preterm birth } \\
\hline \multicolumn{7}{|l|}{ Violent crimes } \\
\hline 1st quintile & Ref. & & & & & \\
\hline 2nd quintile & 1.17 & $0.86-1.59$ & 0.327 & 1.16 & $0.84-1.59$ & 0.367 \\
\hline 3rd quintile & 0.98 & $0.65-1.48$ & 0.918 & 1.01 & $0.66-1.54$ & 0.958 \\
\hline 4th quintile & 1.29 & $0.98-1.72$ & 0.070 & 1.35 & $1.01-1.80$ & 0.040 \\
\hline 5th quintile & 0.97 & $0.71-1.34$ & 0.870 & 1.01 & $0.72-1.40$ & 0.969 \\
\hline Physical abuse & & & & 1.62 & $0.77-3.44$ & 0.206 \\
\hline Depression & & & & 0.81 & $0.32-2.08$ & 0.662 \\
\hline Diabetes & & & & 0.94 & $0.39-2.23$ & 0.884 \\
\hline
\end{tabular}

OR: odds ratio; 95\% Cl: 95\% confidence interval; All analyses used multiple imputations. Imputed data were averaged across the 50 imputed data sets using Rubin's rule [41]. *Adjusted for maternal age, child sex (female), education, and socioeconomic status. 


\section{Unadjusted}

\begin{tabular}{llll} 
Hypertension & 1.21 & $0.76-1.91$ & 0.425 \\
\hline Smoke & 2.04 & $1.47-2.82$ & $<0.001$ \\
\hline Drink & 1.18 & $0.79-1.76$ & 0.420
\end{tabular}

Adjusted $^{*}$

1.18

\section{Low birth weight}

Violent crimes

\begin{tabular}{lllllll} 
1st quintile & Ref. & & & & & \\
\hline 2nd quintile & 1.38 & $1.00-1.91$ & 0.050 & 1.37 & $0.98-1.91$ & 0.063 \\
\hline 3rd quintile & 1.32 & $0.88-1.99$ & 0.178 & 1.36 & $0.89-2.07$ & 0.153 \\
\hline 4th quintile & 1.48 & $1.10-1.99$ & 0.010 & 1.50 & $1.11-2.05$ & 0.009 \\
\hline 5th quintile & 1.42 & $1.04-1.95$ & 0.029 & 1.42 & $1.03-1.98$ & 0.034 \\
\hline Physical abuse & & & & 2.12 & $1.03-4.36$ & 0.042 \\
\hline Depression & & & & 0.71 & $0.22-2.25$ & 0.557 \\
\hline Diabetes & & & & 0.30 & $0.07-1.30$ & 0.107 \\
\hline Hypertension & & & & 1.73 & $1.10-2.71$ & 0.017 \\
\hline Smoke & & & & 2.89 & $2.07-4.03$ & $<0.001$ \\
\hline Drink & & & & 1.14 & $0.77-1.69$ & 0.522 \\
\hline
\end{tabular}

OR: odds ratio; $95 \% \mathrm{Cl}: 95 \%$ confidence interval; All analyses used multiple imputations. Imputed data were averaged across the 50 imputed data sets using Rubin's rule [41]. *Adjusted for maternal age, child sex (female), education, and socioeconomic status·

\section{Discussion}

In this study, we use a novel data set from Brazil to explore the empirical associations between neighborhood-level exposure to violent crime and birth outcomes. Our study yields three main findings: first, exposure to violent crimes is very high among pregnant women in the urban areas studied. Based on the São Paulo estimated population by the Brazilian Institute of Geography and Statistics, and violent crimes reports extracted by us from the Secretariat of Public Safety of the State of São Paulo, from 2011 to 2014 , there were on average 2.87 violent crimes per 10,000 inhabitants in the city of São Paulo and an average of 3.62 violent crimes per 10,000 inhabitants in the study area. While these numbers may be somewhat abstract, they imply that each person living in a densely populated area like the one studied with an estimated density of 7,770 inhabitants per $\mathrm{km}^{2}$ - experiences, on average, 0.94 violent crimes per month within 1-km walking distance from home. For the average pregnant mother, this implies 5.6 crimes in close vicinity within the first six months of pregnancy. Even mothers will, with all likelihood, personally 
witness only a small fraction of these events, the threat of external violence is without any doubt real and constantly present.

Second, our results suggest that external violence should not be interpreted as homogeneous characteristics of entire cities or larger census tracts, but something that is highly heterogeneous within relatively small spatial areas. As shown in Fig. 1, the distance between some of the safest and some of the most violent exposed neighborhoods is less than $2 \mathrm{~km}$, highlighting the remarkable small scale at which urban disparities can be detected.

Third, and maybe most importantly, we found that exposure to crime is associated with substantial increases in SGA, PT, and LBW even after controlling for SES status and maternal education, which is somehow surprising. Our findings that violence increases adverse birth outcomes are consistent with a previous municipality-level comparison from Brazil [20] and highlight the critical long-run consequences of violence beyond the immediate impact on the directly affected population. However, in their study, the authors found a pronounced difference among children of poorly educated mothers, suggesting that violence is only a component of the disadvantages that these children are exposed to as a result of low SES [20]. Similarly, another study found that neighborhood-level socio-economic-related risks have direct effects on LBW and PT, these effects are mediated by personal-level risks such as SES status [42].

The general literature on violence exposure and birth outcomes has been more mixed with some studies such as Messer et al. [19] finding no associations with adverse birth outcomes and others such as Goin et al. [22] finding only an association between first-trimester exposure and SGA. While several theoretical mechanisms highlighted in the literature and introduction of this paper seem consistent with the results presented here, we do not have data to directly investigate mechanisms such as blood pressure increases [43] and anxiety [44] highlighted in the literature. HPA axis activation would be consistent with the PT delivery increase documented in several epidemiological studies [45-49]. It is also possible that heightened maternal cortisol levels may lead to an increased placental corticotrophin-release $[45,49,50]$. Although placental enzymes protect the fetus from increased maternal cortisol levels in principle, animal studies suggest that prenatal stress can affect the placental activity and in utero enzyme expression [51, 52].

It is expected that by 2050 more than a billion children will be living in urban areas [53]. Rapid rates of urbanization combined with increasing economic inequalities are likely to trigger increased rates of violent crime in many settings, especially in areas where access to basic education and health care services remains limited $[53,54]$. Intersectoral strategies to decrease violence are urgently needed, and health programs must be improved to support victims of all kinds of violence.

\section{Limitations}

The analysis presented in this paper has some limitations. Although violence exposure during the third trimester of pregnancy is likely to trigger adverse birth outcomes, our study only considered violence exposure during the first two trimesters of pregnancy. The primary reason for this was the presence of 
early preterm children (24-28 gestational weeks) in our sample, which did not allow us to compute thirdtrimester exposure variables. Excluding these cases, or computing only partial exposures would likely have resulted in substantial estimation bias. It is also not clear how complete the violence data is. The National System of Statistics on Public Security and Criminal Justice [54] classifies each State as having low, medium, or high-quality data, according to the extent of its data coverage and the proportion of deaths with undetermined causes, and São Paulo is in the high-quality group data. It is possible that our data still underestimates the number of crimes in the area because of non-reported or non-registered crimes; we believe that this type of measurement error should, however, be small in the setting studied.

\section{Conclusions}

The results presented in this paper suggest that exposure to external violent crime is associated with substantial increases in small-for-gestational-age, preterm and low birth weight births. Actions to prevent violence or to reduce its impacts need to be implemented to improve neighborhood safety and to reduce inequalities among disadvantaged populations may have large long-term benefits on population health and wellbeing.

\section{Abbreviations}

HIC: High-income countries

LMICs: Low-middle-income countries

ROC-Cohort: Western Region Birth Cohort (Região Oeste Coorte)

LBW: Low birth weight

PT: Preterm delivery

SGA: Small-for-gestational-age

SES: Socioeconomic status

PCA: Principal component analysis

MICE: Multiple imputations by chained equations

95\%Cl: $95 \%$ confidence interval

SD: Standard deviation

OR: Odds ratio

\section{Declarations}


The Ethics Committee for the Analysis of Research Projects (Comissão de Ética para Análise de Projetos de Pesquisa, CAPPesq) of the University Hospital of the School of Medicine of the University of São Paulo (HCFMUSP) approved this study under protocol number: 01604312.1.0000.0065. All mothers who agreed to participate in the ROC-Cohort signed the consent form after being informed about the study and after all questions were answered by trained interviewers.

\section{Consent for publication}

Not applicable.

\section{Availability of data and materials}

The violence information used in this study is publicly available at the Secretariat of Public Safety of the State of São Paulo webpage: www.ssp.sp.gov.br. The individual data that support the findings of this study include personal information such as residential address and health-related data. Therefore, the data are not publicly available. The data can be made available upon reasonable request to the corresponding author after obtaining permission from the University Hospital of the School of Medicine of the University of São Paulo's Ethics board in accordance with the ethics policy statements related to the study protocol.

\section{Competing Interests}

The authors declare that they have no competing interests.

\section{Funding}

This study was financed in part by the Coordenação de Aperfeiçoamento de Pessoal de Nível Superior Brasil (CAPES) - Finance Code 001. The funding agency had no role in the analysis, collection, and interpretation of data, nor did it in the writing process.

\section{Author's contributions}

ACS, AB, and GF contributed to the conception and design of the study. ACS coded the exposure data collection and geocoding, designed the maps, tables and figures, performed the statistical analysis and drafted the manuscript. $A B$, as the principal investigator of the ROC cohort, coordinated and supervised data collection, contributed to the analysis and interpretation of the results, and critically reviewed the manuscript. GF supervised data collection, cleaned the data, provided the analysis plan, contributed to the analysis and interpretation of the results, and critically reviewed the manuscript. All authors read and approved the final version of the manuscript.

\section{Acknowledgments}


Not applicable.

\section{References}

1. Blencowe H, Krasevec J, de Onis M, Black RE, An X, Stevens GA, et al. National, regional, and worldwide estimates of low birthweight in 2015, with trends from 2000: a systematic analysis. Lancet Glob Heal. 2019;7:e849-60. doi:10.1016/S2214-109X(18)30565-5

2. Chawanpaiboon S, Vogel JP, Moller A-B, Lumbiganon P, Petzold M, Hogan D, et al. Global, regional, and national estimates of levels of preterm birth in 2014: a systematic review and modelling analysis. Lancet Glob Heal. 2019;7:e37-46. doi:10.1016/S2214-109X(18)30451-0

3. Barker DJ, Osmond C. Infant Mortality, Childhood Nutrition, and Ischaemic Heart Disease in England and Wales. Lancet. 1986;1:1077-81. doi:10.1016/s0140-6736(86)91340-1

4. Kramer MS. Determinants of low birth weight: methodological assessment and meta-analysis / M. S. Kramer. Bull World Heal Organ 1987; 65(5) 663-737. 1987;

5. Seckl JR, Holmes MC. Mechanisms of Disease: glucocorticoids, their placental metabolism and fetal "programming" of adult pathophysiology. Nat Clin Pract Endocrinol Metab. 2007;3:479-88. doi:10.1038/ncpendmet0515

6. O'Donnell K, O'Connor TG, Glover V. Prenatal Stress and Neurodevelopment of the Child: Focus on the HPA Axis and Role of the Placenta. Dev Neurosci. 2009;31:285-92. doi:10.1159/000216539

7. Lewis AJ, Austin E, Galbally M. Prenatal maternal mental health and fetal growth restriction: a systematic review. J Dev Orig Health Dis. 2016;7:416-28. doi:10.1017/S2040174416000076

8. World Health Assembly 49. Prevention of violence: public health priority. World Health Organization; 1996;(Agenda item 30.2).

9. Krug EG et al., eds. World report on violence and health. Geneva, World Health Organization, 2002.

10. World Health Organization. Global status report on violence prevention 2014. World Health Organization; 2014.

11. World Health Organization. Health in 2015: from MDGs, millennium development goals to SDGs, sustainable development goals. World Health Organization, 2015. World Health Organization;

12. World Health Organization. Health in 2015: from MDGs, millennium development goals to SDGs, sustainable development goals. World Health Organization, 2015. World Health Organization; Available from: https://www.who.int/violence_injury_prevention/violence/status_report/2014/en/

13. García-Moreno C, Pallitto C, Devries K, Stöckl H, Watts C, Abrahams N. Global and regional estimates of violence against women: prevalence and health effects of intimate partner violence and nonpartner sexual violence. World Health Organization; 2013.

14. Ross CE, Mirowsky J. Neighborhood disadvantage, disorder, and health. J Health Soc Behav. 2001;42(3)258-276.

15. Lorenc T, Petticrew M, Whitehead M, Neary D, Clayton S, Wright K, et al. Fear of crime and the environment: systematic review of UK qualitative evidence. BMC Public Health. 2013;13:496. 
doi:10.1186/1471-2458-13-496

16. McEwen BS. Protective and Damaging Effects of Stress Mediators. Flier JS, Underhill LH, editors. N Engl J Med. 1998;338:171-9. doi:10.1056/NEJM199801153380307

17. Zapata BC, Rebolledo A, Atalah E, Newman B, King MC. The influence of social and political violence on the risk of pregnancy complications. Am J Public Health. 1992;82:685-90. doi:10.2105/AJPH.82.5.685

18. Morenoff JD. Neighborhood Mechanisms and the Spatial Dynamics of Birth Weight. Am J Sociol. 2003;108:976-1017. doi:10.1086/374405

19. Messer LC, Kaufman JS, Dole N, Herring A, Laraia BA. Violent crime exposure classification and adverse birth outcomes: a geographically-defined cohort study. Int J Health Geogr. 2006;5:22. doi:10.1186/1476-072X-5-22

20. Foureaux Koppensteiner M, Manacorda M. Violence and birth outcomes: Evidence from homicides in Brazil. J Dev Econ. Elsevier B.V.; 2016;119:16-33. doi:10.1016/j.jdeveco.2015.11.003

21. Matoba N, Reina M, Prachand N, Davis MM, Collins JW. Neighborhood Gun Violence and Birth Outcomes in Chicago. Matern Child Health J. 2019;23:1251-9. doi:10.1007/s10995-019-02765-w

22. Goin DE, M. Gomez A, Farkas K, Zimmerman SC, Matthay EC, Ahern J. Exposure to Community Homicide During Pregnancy and Adverse Birth Outcomes. Epidemiology. 2019;30:713-22. doi:10.1097/EDE.0000000000001044

23. Mayne SL, Pool LR, Grobman WA, Kershaw KN. Associations of neighbourhood crime with adverse pregnancy outcomes among women in Chicago: analysis of electronic health records from 2009 to 2013. J Epidemiol Community Health. 2018;72:230-6. doi:10.1136/jech-2017-209801

24. Felker-Kantor E, Wallace M, Theall K. Living in violence: Neighborhood domestic violence and small for gestational age births. Health Place. 2017;46:130-6. doi:10.1016/j.healthplace.2017.05.011

25. Messer LC, Kaufman JS, Dole N, Savitz DA, Laraia BA. Neighborhood Crime, Deprivation, and Preterm Birth. Ann Epidemiol. 2006;16:455-62. doi:10.1016/j.annepidem.2005.08.006

26. Clemens T, Dibben C. Living in stressful neighbourhoods during pregnancy: an observational study of crime rates and birth outcomes. Eur J Public Health. 2016;ckw131. doi:10.1093/eurpub/ckw131

27. Brown R. The Mexican Drug War and Early-Life Health: The Impact of Violent Crime on Birth Outcomes. Demography. 2018;55:319-40. doi:10.1007/s13524-017-0639-2

28. Urdinola-Contreras BP. War is not healthy. Political violence and infant health outcomes in Colombia. Rev Salud Pública. 2018;20:326-33. doi:10.15446/rsap.v20n3.55430

29. Comacho A. Stress and Birth Weight: Evidence from Terrorist Attacks. Am Econ Rev. 2008;98:511-5. PMID: 29135213

30. United Nations, Department of Economic and Social Affairs, Population Division (2019). World Urbanization Prospects: The 2018 Revision (ST/ESA/SER.A/420). New York: United Nations.

31. Cardia, Nancy. Urban Violence in São Paulo. Washington, D.C.: Woodrow Wilson International Center for Scholars (Comparative Urban Studies Occasional Papers Series, 33), 2000. 
32. GINI index (World Bank estimate). Available from: data.worldbank.org/indicator/SI.POV.GINI

33. Cerqueira D, Bueno S, Lima RS de, Cristina N, Helder F, Paloma Palmieri A, et al. Atlas da violência 2019. Instituto de Pesquisa Econômica Aplicada (Ipea); 2019;

34. Rodrigues A, Hernandes R, Mariani D, Bergamo M. Mapa da morte em SP. 2017 [cited 2020 Feb 15]. Available from: http://temas.folha.uol.com.br/mapa-da-morte/introducao/mapa-da-morte-em-sp-vaida-suecia-ate-o-mexico-locais-dos-crimes-se-repetem.shtml

35. Ballard JL, Khoury JC, Wedig K, Wang L, Eilers-Walsman BL, Lipp R. New Ballard Score, expanded to include extremely premature infants. J Pediatr. 1991;119:417-23. doi:10.1016/S00223476(05)82056-6

36. Villar J, Ismail LC, Victora CG, Ohuma EO, Bertino E, Altman DG, et al. International standards for newborn weight, length, and head circumference by gestational age and sex: the Newborn CrossSectional Study of the INTERGROWTH-21 st Project. Lancet. 2014;384:857-68. doi:10.1016/S01406736(14)60932-6

37. Kahle D, Wickham H. ggmap Spatial Visualization with ggplot2. R J. 2013;5:144-61. Available from: httpsjournal.r-project.orgarchive2013-1kahle-wickham.pdf

38. R Core Team. R: A Language and Environment for Statistical Computing. Vienna, Austria; 2019. Available from: http://www.r-project.org/

39. Vyas S, Kumaranayake L. Constructing socio-economic status indices: how to use principal components analysis. Health Policy Plan. 2006;21:459-68. doi:10.1093/heapol/czl029

40. StataCorp. 2015. Stata Statistical Software: Release 14. College Station, TX: StataCorp LP.

41. Rubin DB. Multiple imputation for nonresponse in surveys. John Wiley \& Sons; 2004.

42. Meng G, Thompson ME, Hall G. Pathways of neighbourhood-level socio-economic determinants of adverse birth outcomes. Int J Health Geogr. 2013;12:32. doi:10.1186/1476-072X-12-32

43. Wilson DK, Kliewer W, Sica DA. The relationship between exposure to violence and blood pressure mechanisms. Curr Hypertens Rep. 2004;6:321-6. doi:10.1007/s11906-004-0028-2

44. Pynoos RS. Traumatic stress and developmental psychopathology in children and adolescents. In: Oldham JM, Riba MB and Tasman A, editor. American Psychiatric Press Review of Psychiatry. Vol. 12. Washington DC, American Psychiatric Association; 1993.

45. Wadhwa PD, Garite TJ, Porto M, Glynn L, Chicz-DeMet A, Dunkel-Schetter C, et al. Placental corticotropin-releasing hormone $(\mathrm{CRH})$, spontaneous preterm birth, and fetal growth restriction: $A$ prospective investigation. Am J Obstet Gynecol. 2004;191:1063-9. doi:10.1016/j.ajog.2004.06.070

46. Giurgescu C. Are Maternal Cortisol Levels Related to Preterm Birth? J Obstet Gynecol Neonatal Nurs. 2009;38:377-90. doi:10.1111/j.1552-6909.2009.01034.x

47. Compas BE. Psychobiological Processes of Stress and Coping: Implications for Resilience in Children and Adolescents-Comments on the Papers of Romeo \&amp; McEwen and Fisher et al. Ann N Y Acad Sci. 2006;1094:226-34. doi:10.1196/annals.1376.024 
48. McEwen BS. Physiology and Neurobiology of Stress and Adaptation: Central Role of the Brain. Physiol Rev. 2007;87:873-904. doi:10.1152/physrev.00041.2006

49. Beijers R, Buitelaar JK, de Weerth C. Mechanisms underlying the effects of prenatal psychosocial stress on child outcomes: beyond the HPA axis. Eur Child Adolesc Psychiatry. 2014;23:943-56. doi:10.1007/s00787-014-0566-3

50. Majzoub JA, Karalis KP. Placental corticotropin-releasing hormone: Function and regulation. Am J Obstet Gynecol. 1999;180:S242-6. doi:10.1016/S0002-9378(99)70708-8

51. Mairesse J, Lesage J, Breton C, Bréant B, Hahn T, Darnaudéry M, et al. Maternal stress alters endocrine function of the feto-placental unit in rats. Am J Physiol Metab. 2007;292:E1526-33. doi:10.1152/ajpendo.00574.2006

52. Jensen Peña C, Monk C, Champagne FA. Epigenetic effects of prenatal stress on 11ß-hydroxysteroid dehydrogenase-2 in the placenta and fetal brain. PLoS One. 2012;7:e39791. doi:10.1371/journal.pone.0039791

53. World Health Organization. Global report on urban health: equitable healthier cities for sustainable development. World Health Organization; 2016; Available from: https://apps.who.int/iris/handle/10665/204715

54. Unicef. The state of the world's children 2012: children in an urban world. eSocialSciences; 2012.

55. Lima RS de, Bueno S, Martins C, Marques D, Pröglhöf PN, Astolfi R, et al. $9^{\circ}$ Anuário Brasileiro de Segurança Pública. 2015. Available from: http://www.forumseguranca.org.br/storage/9_anuario_2015.retificado_.pdf

56. StataCorp. 2015. Stata 14 Base Reference Manual. College Station, TX: Stata Press.

\section{Figures}




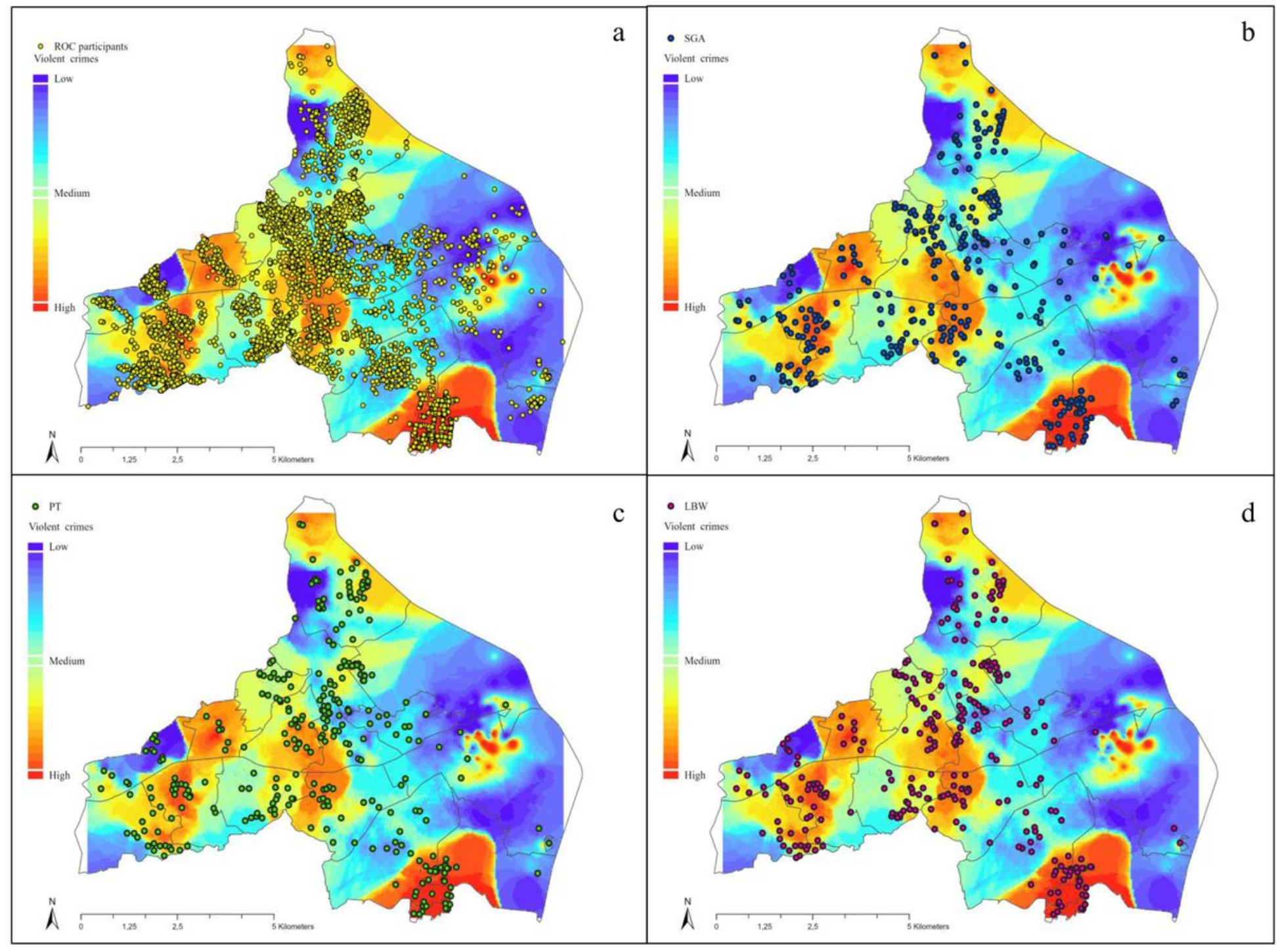

Figure 1

Heatmap of the Butantã-Jaguaré Region of São Paulo showing the distribution of violent crimes during pregnancy. Blue indicates lower number of violent crimes incidents and red higher. The point layers show the geographic distribution of ROC residences (a), infants born small for gestational age (b), preterm births (c), and low birth weight (d). 

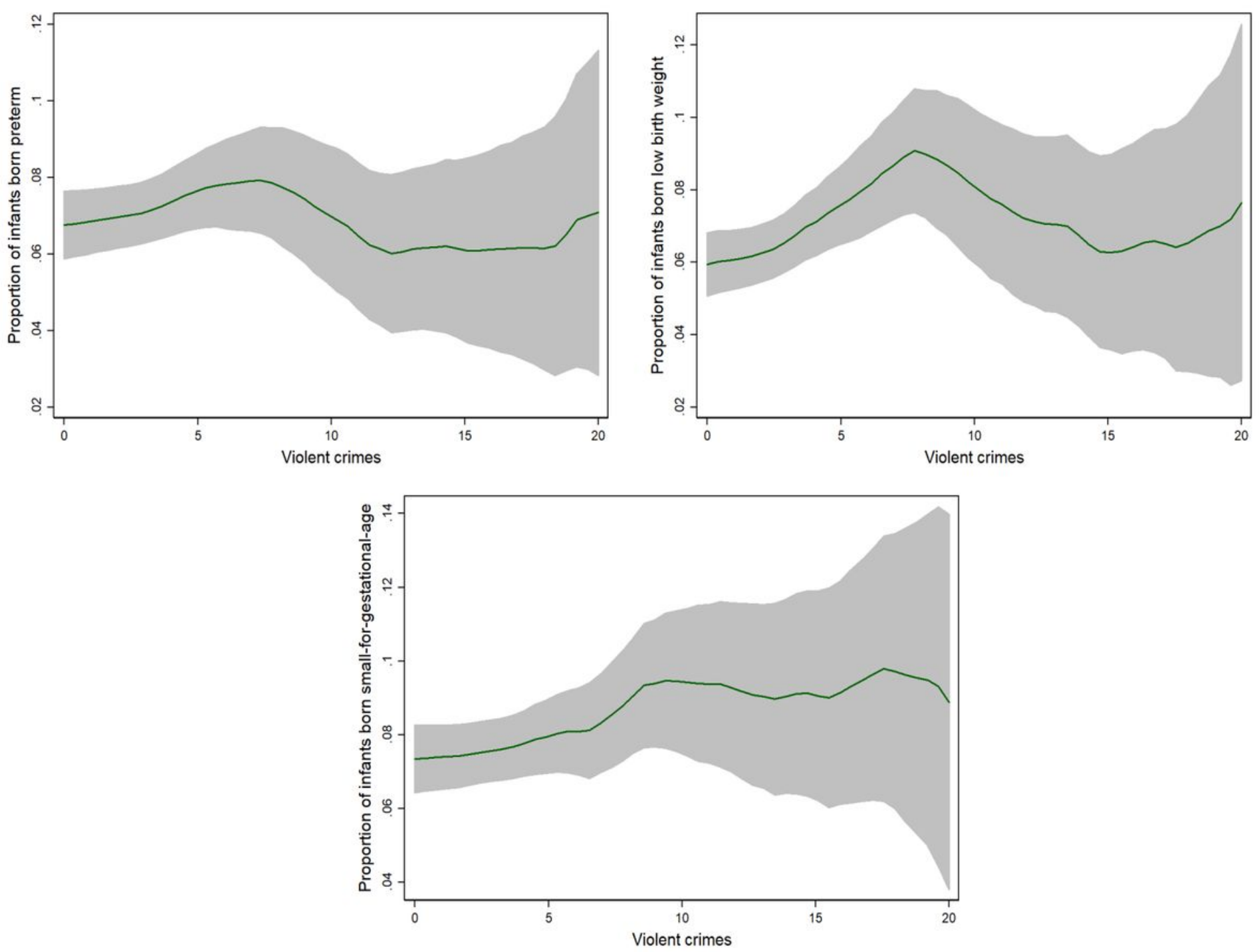

Figure 2

Exposure to violent crime and average birth outcomes. The figure shows log polynomial smoothed relationship between violent crime exposure and preterm birth (a), low birth weight (b), and small-forgestational-age (c).

\section{Supplementary Files}

This is a list of supplementary files associated with this preprint. Click to download.

- SupplementaryMaterial.docx

- Supplementaryfile2.docx

- Supplementaryfile1.docx 